\title{
31. Tatar yazar Galiesgar Kamal'ın İstanbul Mektupları adlı eserinde toplumsal hayat ve Türk imgesi
}

\section{İlsever RAMI'}

APA: Rami, İ. (2021). Tatar yazar Galiesgar Kamal'ın İstanbul Mektupları adlı eserinde toplumsal hayat ve Türk imgesi. RumeliDE Dil ve Edebiyat Araştırmaları Dergisi, (23), 473-484. DOI: 10.2900o/rumelide.949049.

\section{$\ddot{\mathbf{O} z}$}

Ístanbul Mektuplar, Tatar tiyatro yazarı ve gazeteci Galiesgar Kamal tarafindan 1912-1913 yıllarında Balkan Savaşı ve o dönem İstanbul'unda yaşananları yazdığı seyahatname türünde bir eserdir. Yazar, Balkan Savaşı'nı yakından takip ederek Tatar basınına haberler gönderebilmek için İstanbul'a gelir ve burada olup bitenlere tanıklık eder. Galiesgar Kamal yazllarında savaş dönemi İstanbul'undaki gözlemlerinin yanı sıra Tatar okuru için Osmanlı hayatıyla ilgili ilginç ve merak edilen konuları da ele alır. Ayrıca yazar, 23 Ocak 1913 tarihinde gerçekleşen Hükümet Darbesinin şahidi olur ve bu olayları ayrıntılı bir şekilde aktarmaya çalışır. Aynı zamanda Osmanlı İmparatorluğu'nda gerçekleşen reform ve yeniliklerden de bahsederek reform sürecinin Türk toplumu için önemini gözler önüne serer. Ancak hiç beklenmedik bir anda hastalanır ve bu nedenle de sadece birkaç ay İstanbul'da kalarak tedavi için memleketine geri dönmek zorunda kalır. İstanbul'da bulunduğu süreç boyunca yazdığı 12 mektubun hepsi de Kamal'ın çalıştığı Yoldız Gazetesi'nde yayımlanır. İstanbul Mektupları eserinde savaş dönemindeki devletin çatışmalı iç siyaseti, halkın vatanseverlik duyguları, sosyal ve kültürel yaşamı ayrıntılı bir şekilde tasvir edilmiştir. İstanbul seyahati sırasında yazar yeni kültür ve yaşam tarzı ile tanışmış; kendi kültürel öğeleri ile karşılaştırma fırsatı elde etmiştir. Karşılaştırmalı Edebiyat kapsamında ele alınan bu makalede Tatar yazar Kamal'ın İstanbul Mektupları eserinin toplumların birbirini tanıması ve etkileşimi üzerine yaptı̆̆ı katkıyı gözler önüne sermektir.

Anahtar kelimeler: Galiesgar Kamal, İstanbul Mektupları, karşilaştırmali edebiyat

\section{Social life and Turkish image in Istanbul Letters by Tatar writer Galiesgar Kamal}

\begin{abstract}
Istanbul Letters is a travel writing in which Tatar theater writer and journalist Galiesgar Kamal describes the events of the Balkan War in 1912-1913 and the events in Istanbul. The author comes to Istanbul to report back to the Tatar press by following the Balkan War closely and he witnesses the events what happened here. The writer starts his journey in Kazan, passes through Moscow and Odessa cities, from there he reaches Istanbul. Galiesgar Kamal, in his writings, along with documenting his observations of Istanbul during the Balkan War, he tried to deliver interesting and wondered subjects about Ottoman life for the Tatar reader. The author witnesses the Government Coup incidents that took place on 23 January 1913 while he was in Istanbul and tries to document the incident thoroughly. At the same time, the author talks about the reforms and changes that took place in the Ottoman Empire. It underlines the importance of these reforms and the renewal
\end{abstract}

Dr. Öğr. Üyesi, Yeditepe Üniversitesi, Fen Edebiyat Fakültesi, Rus Dili ve Edebiyatı Bölümü (İstanbul, Türkiye) ilsever.rami@yeditepe.edu.tr, ORCID ID: 0ooo-0003-4322-7478. [Araştırma makalesi, Makale kayıt tarihi: 10.04.2021kabul tarihi: 20.06.2021; DOI: 10.29000/rumelide.949049]

Adres $\mid$ Address

RumeliDE Dil ve Edebiyat Araşttrmaları Dergisi $\quad$ RumeliDE Journal of Language and Literature Studies Osmanağa Mahallesi, Mürver Çiçeği Sokak, No:14/8 Osmanağa Mahallesi, Mürver Çiçeği Sokak, No:14/8

Kadıköy - İSTANBUL / TÜRKIYE 34714 Kadıköy - ISTANBUL / TURKEY 34714 e-posta: editor@rumelide.com

e-mail: editor@rumelide.com,

tel: +90 505 7958124, +90 2167730616 phone: +90 505 7958124, +90 2167730616 


\begin{abstract}
process for Turkish society. Unfortunately, he stayed in Istanbul for only a few months due to unexpected illness, compelling him to seek treatment returning to hometown. During his stay in Istanbul, he wrote 12 letters which were published in Yoldı Newspaper where Galiesgar Kamal worked. In these letters, Galiesgar Kamal described in detail the conflictual domestic policy of the state, the patriotic feelings of the Turks, and the social life and culture of the society. During his Istanbul trip, the author met the new culture and lifestyle; he had also the opportunity to compare them with his own cultural elements. This article, which is discussed within the scope of the Comparative Literature approach, reveals the contribution of the Istanbul Letters of Tatar writer G. Kamal to the recognition and interaction of the Tatar and Turkish societies.
\end{abstract}

Keywords: Galiesgar Kamal, Istanbul Letters, comparative literature

\title{
Giriş
}

Galiesgar Kamal (1878-1933) yazdığı çok sayıdaki dram ve komedi eserleriyle tanınan, Tatar tiyatrosunun oluşumuna büyük katkılarda bulunan ünlü tiyatro yazarıdır. "Yaratıcılığın başlangıcında kendini bütün edebi türlerde dener: şiirler, hikâyeler, piyesler yazar, tercüme işleri yapar, eleştiri makaleleri yazar" (Zaripova Çetin, 2018: 616). Bütün bunların yanı sıra Kamal başarılı bir gazetecidir. Gazetecilik faaliyetlerine Kazan'da yayımlanan Kazan Muhabiri adlı ilk Tatar gazetesinde başlar. "Kendisi de yıllardır gazete ve dergiler neşretmiş, yazı işleri müdürü olduğu Yoldız Gazetesi”nde hiciv yazıları, siyaset ve toplumsal sorunlara, uluslararası ilişkilere değinen makaleleri, tiyatro ile ilgili edebi eleştiri yazıları ve güncel konular üzerine çok sayıda makaleleri yayımlanmıştır” (Aleeva, t.y.).

Galiesgar Kamal, Kasım 1912'de Yoldız Gazetesi’nin özel muhabiri olarak Türkiye'ye gelir. Kasım 1912 - Şubat 1913 tarihleri arasında İstanbul'da bulunur; hastalanınca Kazan'a geri dönmek zorunda kalır. Yazarın amacı, Balkan Birliği ülkeleri ile Osmanlı arasında başlayan savaşı ve Osmanlı İmparatorluğu'nda gerçekleşen reform sürecini Tatar okurlarına anlatmaktır. Kamal'ın bu süreç sonunda yazdığı mektupları, Yoldız Gazetesi’nin 1912 yılı sonu ve 1913 yılı başı sayılarında İstanbul Mektupları adı altında yayımlanmıştır. Aralarında üç tanesi farklı isimlerle: ilk mektup "İstanbul'a Varış Yolunda", on birinci mektup "Türkiye'de Büyük Değişimler", on ikinci mektup "Son Gün Hatıraları" olarak adlandırılmıştır. On iki ayrı mektuptan oluşan bu eser, Kazan'da yayımlanmış Galiesgar Kamal’n Eserleri derlemesinin üçüncü cildinde yer almaktadır. İstanbul Mektupları 2020 yılında M. Öner'in aktarımıyla “Türk Dünyası Dil ve Edebiyat Dergisi”nde Türkçe de yayımlanmıştır.

Prof.Dr. Galiesgar Kamal'ın İstanbul'a özel muhabir olarak gönderilmesinin elbette önemli sebepleri bulunmaktadır. İstanbul ve Osmanlı Devleti, çok eskiden beri Tatarlar için büyük önem taşıyan kültürel ve dini merkez olmuştur. Tatar yazar ve araştırmacı Eydi’nin de belirttiği gibi Türk ve Tatar halkları arasında XX. yüzyılın başlarında sağlamlaşan bağlar "Tatar halkının yeniden uyanmasına, eğitimin nitelik ve sayıca yeterli duruma getirilmesine, edebiyat ve sanatın canlanmasına, süreli basının yayımlanmaya başlamasına ve geniş kitlelere ulaşmasına, onların aydınlanmasına ab-i hayat içirilmiş gibi sihirli bir tesiri olmuştur" (Eydi, 2004:303-304).

O yillarda, birçok Tatar genç İstanbul'da çeşitli okullarda eğitim görür, buradaki yaşamın içinde yer edinmiştir. Aynı zamanda Kazan'da yayımlanan gazete ve dergiler için yazılar ve makaleler göndermişlerdir. Tatar okurları da dini ve manevi merkez olarak gördükleri Osmanlı'yla ilgili haberlere büyük ilgi duymuş, olup bitenleri yakından takip etmeye çalışmışlardır. Galiesgar Kamal ile aynı dönemde, diğer bir ünlü Tatar yazarı Fatih Kerimi (1870-1937) de Balkan Savaşı ile ilgili gelişmeleri

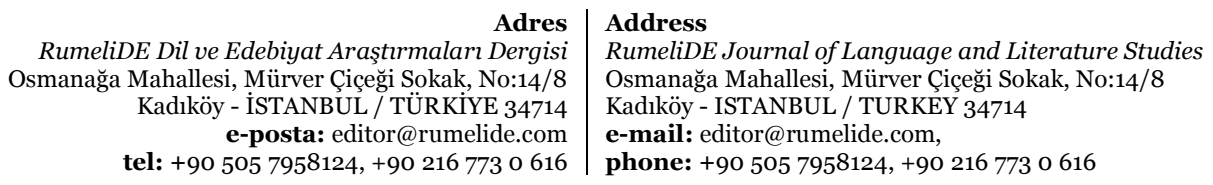


takip etmek için İstanbul'a gelir ve aynı adla isimlendirdiği İstanbul Mektupları denemelerini yayımlamaya başlar. Onun yazıları ilk önce Vakit Gazetesi ve Şura Dergisi’nde; sonra da Orenburg'ta 70 bölümden oluşan bir kitap olarak yayımlanır. Türkçeyi ve Türk edebiyatını iyi bilen, Arapça, Farsça ve Fransızca dillerine vakıf olan, 1896 yllında İstanbul'da Mekteb-i Mülkiyye'den mezun olan Fatih Kerimi, Tatar okurları için Türkiye'nin siyasetini, kültürünü, milli eğitim sistemini ve tarihini kendi bakış açısıyla değerlendirerek sunmuştur. İki Tatar aydınının, aynı zamanda savaş dönemi yaşam biçimi, askeri ve sivil halkın savaşa bakış açısı, devlet yöneticilerinin yürüttüğü iç ve dış siyaset, çeşitli siyasi partiler, onların iktidara gelmek için kendi aralarında verdikleri mücadeleler hakkında etraflıca yazdıkları makaleleri Tatarlar için çok ilgi çekici olmuştur. Bu dönemde Tatar yazarların gezi izlenimlerini okuyucuya aktarırken mektup türüne başvurmalarının yaygın olduğunu söyleyebiliriz. Kefeli'nin de belirttiği gibi "Gezi izlenimlerini okuyucularına nakletmek isteyen yazarlarımız da mektuptan sık sık yararlanmışlar. Zaten bir haberleşme aracı olan mektup seyyahların gördüklerini, yaşadıklarını okuyucularına ulaştırmaları için ideal bir tür olmuş ve onlara kolaylık sağlamıştır" (Kefeli, 2002:29).

\section{Kazan'dan İstanbul'a uzanan yolculuk}

Rusya'dan gelen birçok gezgin gibi Galiesgar Kamal da İstanbul'a deniz yoluyla Odessa üzerinden ulaşır. Yazar, ilk başta Kazan'dan trenle Moskova'ya geçer; burada ilgisini çekecek türden herhangi bir durum ve olayın yaşanmadığını belirtir. Ancak Moskova'da satın aldığı Rus gazetelerinde Türkiye'nin Balkan Birliği hükümetleriyle geçici anlaşmaya vardığına, sulh ilan edildiğine dair haberlerin yer aldığını görür. Anlaşmayla ilgili yazılan bu haberler, savaş olaylarını gözlemlemeye hazırlanan yazarı biraz olsa da üzmüştür. Moskova hayatı ise yazarın pek ilgisini çekmemiştir. Moskova'nın çoğu yerini gezip şehir ile tanıştıktan sonra "Moskova'daki hayat, sadece Rus hayatıdır" diyerek bunun dışında başka bir değerlendirme yapmaz. Kamal, Moskova'da Müslüman halkın az nüfuslu olduğunu ve onların yaşamlarında Tatar okurları için ilginç detaylara rastlamadığını belirtir. Kamal'ın ilgisini daha çok Müslüman dünyası, Osmanlı İmparatorluğu, Müslüman ve Hristiyanlar arasında devam eden çatışma konuları çekmektedir.

Odessa’ya varınca yazar, orada yayımlanmakta olan Yujnaya Misl Gazetesi (Южная мысль) ve Yujnaya Nedelya Dergisi”nin (Южная неделя) genel yazı işleri müdürü, Polonyalı Tatar Ali Bek Tamarin ile buluşur. Aralarında gerçekleşen sohbette Türkiye ve Rusya Müslümanlarının durumu, Rus gazetelerinde yer alan Balkan Savaşı ile ilgili haberlerin gerçeği yansıtmadığından söz edilir. Tamarin, Rusya Müslümanlarının bilime, eğitime önem verdiğini düşünmekte ve onların istikballerine umutla baktığını bildirmektedir. Müslüman halkların geleceğine dair konular vize işlemleri ile uğraşırken görüsşüğü Türkiye konsolosu Atuf Bey'le sohbet ederken de dile getirilir. Atuf Bey Osmanlı Müslümanlarının sonuna cehaletin sebep olacağını, sadece eğitim ve reformların Türkiye'yi kurtaracağını düşünmektedir.

Odessa'dan İstanbul'a deniz yolculuğu esnasında Kamal ve gemi kaptanı arasında geçen sohbette ise hac yolculuğu yapan Müslümanların sayısında yaşanan düşüş, ibadet imkânlarının kısıtlanmasına dair konular ele alınır. Anlaşıldığı gibi Kamal'ı her şeyden önce Müslüman halkların yaşamı, onların istikbali, gelişimi gibi konular ilgilendirir. Bu da İstanbul Mektupları'nın Rusya ve Osmanlı Müslümanlarının hayatı, onların yaşam biçimleri, eğitim ve sağllk sistemleri, fikir ve düşünceleri, gelecekle ilgili umutları üzerine olmasına yol açmıştır.

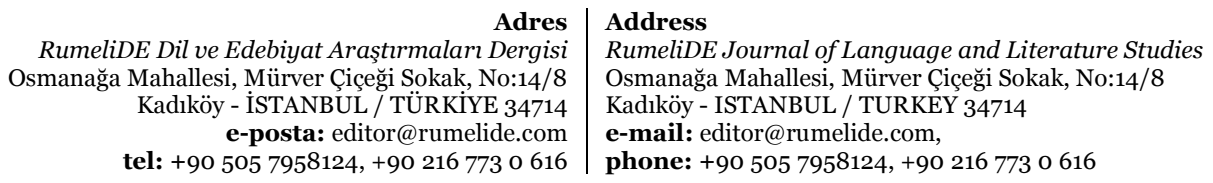

RumeliDE Dil ve Edebiyat Araşttrmaları Dergisi e-posta: editor@rumelide.com tel: +90 505 7958124, +90 2167730616
Address

OsmatiDE Journal of Language and L

e-mail: editor@rumelide.com

phone: +90 5057958124, +90 2167730616 


\section{İstanbul}

Eserde İstanbul manzaralarına geniş yer verilmiştir. Gemi Boğaz sularına girmeye başlayınca yazar, İstanbul'un eşsiz güzelliği ile karşılaşır: "Boğaz’ın görmeye doyum olmayacak manzaraları ardı ardına gözümüzün önünden geçmeye başladı" (Kamal, 2020:124)². Savaş döneminde ülkeye ayak basan yazar ilk bakışta sakin, kendi halinde devam eden günlük yaşam biçimini şöyle tasvir eder: "Her yerde sükûnet var fakat boğaz içine düşman askeri girse onları batırmak için hazırlanmış müthiş toplar iki tarafta da görünüyor" (Kamal, 2020:124). Yazar bu sükûneti gördükten sonra bir an için "Yoksa Türkiye'nin işe yarar bütün insanları cepheye gitti de şehirde sadece çocuklarla ihtiyarlar mı kaldı acaba" düşüncesine kapılır. Ancak ilerledikçe manzara değişir, şehrin sokaklarında insanlar, gemiler görünmeye başlar. Rıhtıma yakınlaşınca yazar, "Deniz gibi dalgalanan, karınca gibi kaynayan" halkı görünce çok sevinir. Sanki yakın zamanda buralarda dehşetli savaşlar olmamış gibi davranan ve "Her birisi iyi, temiz giyinmiş. Âdeta bayram ediyorlar" havasında bulunan insanlarla karşılaşır (Kamal, 2020:124).

Kamal, şehre ayak basar basmaz İstanbul'a ilk gelişindeki hatıralarını tazeleyip karşılaştırmaya başlar. Yazar, şehirde atların kalmamasından dolayı tramvayların çalışmadı̆̆ını, yakın zamanda elektrik ile çalışan tramvayların hizmete başlayacağını, bunun için de yeni yolların yapıldığını; şehirde telefon kullanımını yaygınlaştırmaya yönelik çalışmaların yapıldığını, özellikle de devlet daireleri ve karakollar gibi pek çok yerde telefonla iletişim kurulduğunu ve şehirde elektrik kullanımının yaygınlaşacağına dair söylentileri aktarıyor. Kamal, şehrin düzenlenmesi, yenilenmesi, dar sokakların olabildiğince genişletilmesi, kanalizasyonların gözden geçirilmesi, yollara taş, kaldırımlara asfalt uygulanması gibi olumlu değişikliklerden de bahseder.

İstanbul sokaklarını gezen yazar, caddelerde çok sayıda askerin dolaştığını da belirtir. Kamal, askerlerin Avrupai tarzda giyinmeye başladıklarını, giysilerinin eskisine nazaran daha güzel olduğundan söz eder: "En evvel göze görünen şey askerlerin kiyafetleri oldu. Şimdi her bir asker, Avrupa'nın başka devletlerindeki gibi, mail-i yeşil renkte elbise giymişler, başlarında da evvelki kırmızı fes yerine fese benzer dikilmiş yeşile mail şapkalar. Evvelkine nispeten askerlerin giysileri daha güzel" (Kamal, 2020:125).

İstanbul'da sokağa çıkma yasağı olduğundan akşamları dışarıda gezemeyen Galiesgar Kamal yine de bir dakikasını bile boşa harcamaz. Gündüz saatlerinde çevredeki insanlarla görüşür, sohbet eder, tüm gün şehri gezip dolaşır; hiçbir değişimi, hiçbir olayı gözünden kaçırmamaya çalışır (Aleeva, t.y.).

Savaş beraberinde şehrin düzenine dair birtakım değiş̧iklikler de getirir. Örneğin, İstanbul'un neredeyse tüm eğitim kurumlarında eğitime ara verilir ve her biri hastaneye dönüştürülür; Ayasofya, Sultanahmet, Beyazıt, Fatih gibi camilerin hepsine asker yerleştirilir. Savaşın getirdiği olumsuz etkilerden bahseden yazar "yiyecek erzakın her zamankinden daha pahalı” olduğunu, İstanbul'un hiç değişmez simgelerinden ve çoğu gezginin eserinde yer alan sokak köpeklerinde "hiçbir nam ve nişan kalmadığını" da belirtir. 


\section{Sağllk sistemi}

Kamal, Türkiye'de sağlık sisteminin iyileştirilmesi, eğitim sisteminin yeniden yapılandırılması ve askeri sistemin güçlendirilmesi gibi üç konuya büyük önem verildiğini belirtir. Yazar, sağllk alanında gerçekleştirilen reformları yakından izleyebilmek için İstanbul hastanelerini ziyaret eder. Bu ziyaret esnasında Hilal-i Ahmer'e yardım etmek için Petersburg'dan İstanbul'a gelen Kebir Bekirov, Fatih Rehimov, Şerif Ehmetcanov ve daha dört kadın ile tanışır. Yazar yaralılar ile de sohbet eder; gözlemler yaparak hastanelerin temiz, pak ve düzenli olduğunu şu sözlerle dile getirir: "Hastane pek temiz, hastaların yattıkları yerler de ak pak, hastaneden çıkarken bana dezenfeksiyon yapıp ellerimi ilaçlı suyla yıkadılar" (Kamal, 2020:126).

Galiesgar Kamal, Ermeni ve Rum kadınlarıyla birlikte Müslüman kadınların da hasta baktığını belirtir. Bu satırlarda, Müslüman kadınların da toplum hayatında aktif rol almaya başladıklarının altını çizer. Ancak şunu da belirtmemiz gerekir ki bu detay dışında İstanbul Mektupları'nda Osmanlı kadınlarının günlük hayatı ve toplumdaki yeri gibi konulara neredeyse hiç yer verilmemiştir.

Ziyaret ettiği Tıbbiye Mektebi, hastane ve kışlaların inşaatında kullanılan mermer ve granit taşlar, İstanbul'un güzel mimarisi, Haydarpaşa Garı ve diğer binalar yazarda hayranlık uyandırır:

"Buraya geldikten sonra insan büyük binaları görüp hayran kalıyor. Çünkü kışlalara kadar her bir binayı mermer veya granit taştan yapıyorlar. Bu taş İstanbul'da o kadar ucuzdur ki sıradan bir evin tuvaletlerinden yer döşemelerine kadar mermerden yapılmıştır. Haydarpaşa'daki tren garı dikkate alınacak bir binadır. Almanlar hiç paraya acımamışlar. Dışarıdan bakınca hayran olunası bir bina vücuda getirmişler" (Kamal, 2020:132).

Kamal hastanelerden bahsederken oralarda çalışan doktor ve hemşirelerden de söz eder. Önceki yllarda hastanelerde çalışanların çoğunu Almanya, Avusturya ve Romanya'dan gelen doktorlar oluştururken savaşın başlamasıyla Romanya ve Avusturya'dan gelenler "kendi hükümetlerinin talebiyle memleketlerine" geri dönmek zorunda kahır. Böyle bir zamanda doktorlara büyük ihtiyaç duyan Türkiye, başka ülkelerden doktorlar kabul etmeye başlar:

“Darülfünun hastanesinde her milletten kişi var. Mesela burada Rusya'dan gelen Tatarlar olduğu gibi, Romanyalı, Almanyalı, İngiltereli, Mısırlı, hatta Bulgaristanlı (Müslüman) doktor ve hemşireler var. Daha dün bu hastaneye Hindistan'dan altı Müslüman doktor, on Tıbbiye talebesi ve dört hasta bakıcı geldi. Her biri çok iyi İngilizce konuşuyor, Arapça da biliyorlar. Fakat Türkçe hiçbir şey anlamıyorlar” (Kamal, 2020:132).

Yazar, Kırım Müslümanlarının Osmanlı için yardım parası topladıklarını, iki kişinin de bu toplanan yardım akçesi ve teçhizatı ulaştırmak için İstanbul'a geldiğinden bahseder.

\section{Eğitim sistemi}

Galiesgar Kamal, eserinde Türkiye'nin eğitim sistemini özel olarak ele alır ve milli eğitim konularına ciddi anlamda önem verildiğini belirtir. İstanbul'da İngiliz, Alman, Amerikan, Cizvit okullarının açılmış olduğunu ve hatta o okullarda kız çocuklarının isteyerek eğitim aldıklarını yazar. Son dönemde Türkler bu yabancı okulların "boyunduruğundan kurtulmak için" Türk okulları açmaya başlamış olup Kadıköy'de Haydar Paşa tarafından açılan ve onun adını taşımakta olan okulu Kamal bizzat kendisi gidip görür: "Binası güzel ve temizliği mükemmeldir. Lakin ders vakti olmadığından talim usullerini

\footnotetext{
\begin{tabular}{r|l} 
Adres & Address \\
RumeliDE Dil ve Edebiyat Araşttrmaları Dergisi & RumeliDE Journal of Language and Literature Studies
\end{tabular} Osmanağa Mahallesi, Mürver Çiçeği Sokak, No:14/8 Osmanağa Mahallesi, Mürver Çiçeği Sokak, No:14/8 Kadıköy - İSTANBUL / TÜRKIYE 34714 Kadıköy - ISTANBUL / TURKEY 34714 e-posta: editor@rumelide.com e-mail: editor@rumelide.com, tel: +90 505 7958124, +90 2167730616 phone: +90 505 7958124, +90 2167730616
} 
göremedim. Benimle birlikte gelen arkadaşımın söylediğine göre dersleri de iyi bir program üzere tertip edilmiş” (Kamal, 2020:136). Yazar, yeni okulların açılması ve eğitim öğretim işlerine büyük önem verilmesini toplumsal ilerlemenin bir parçası olarak değerlendirir.

Kamal Türkiye'nin, kendi tabiriyle "en mükemmel okullarından" sayılan Mekteb-i Tibbiyye'yi ziyaret eder. Mermer taşlarla dörtgen şeklinde inşa edilmiş ve son derece güzel mimariye sahip binaya yerleşen Mekteb-i Tıbbiyye'yi ziyaret ederken yazara orada eğitim görmekte olan Rusyalı talebe Sibgatulla eşlik eder. Galiesgar Kamal bu eğitim kurumunda gördüklerini şöyle aktarır:

"Mektep binası harici tertipleri bakımından güzel olduğu gibi dâhili tertiplerinden de güzeldir. Mektebi böyle güzel dereceye ulaştırmak için sadece Türkiye'de değil belki Avrupa'da da ismi yayllan meşhur cerrah Cemil Paşa pek çok içtihatlar sarf etmiştir. Mektepte şimdi ders yok. Mektep hastaneye çevrilmiş. Üç yüz kadar yaralı ve hasta tedavide yatıyor. Beş yüz kadar boş yatak da var. Operasyon salonları pek güzel, kütüphanesi de pek mükemmel. Mektebin yanında botanik bahçesi var. Bahçe nebatatça zengin. Serasına girince kendini âdeta güneydeki memleketlerin birinde gibi hissediyorsun. Her taraftan hurma ve palmiye ağaçlarının yaprakları başına düşüp durmakta. Mektebin karşısında yolun diğer tarafına klinik kurulmuş. Onun binası da çok güzel. $\mathrm{O}$ da aynı mektep gibi mermer taştan inşa edilmiş" (Kamal, 2020:132).

Yazarın Türk okulları ile ilgili bu kadar detaylı bilgi vermesinin amacı Türkiye'de milli eğitim sisteminin ne kadar gelişmiş olduğunu ve milletin istikbali açısından büyük önem taşıdığını vurgulamaktır. Bilindiği üzere o zamanlarda birçok Tatar genci eğitim amaçlı Türkiye'ye gelir ve buradaki eğitim sistemi ile yakından tanışır. Dahası ana diline yakın dilde eğitim alarak aynı dini muhitte yaşama imkânı bulur.

\section{Askeri müze}

Galiesgar Kamal, Tatar okurlarını İstanbul'un kültür ve sanat hayatı ile tanıştırmak için Ayasofya Meydanı'nda bulunan Askeri Müzeyi ziyaret eder. "Gündüz saat on ikiden itibaren güneş batıncaya kadar” müzeyi gezen yazar "oradaki zenginlikleri seyretmeyi bitiremez”. Kamal, Askeri Müze'de sergilenen eserlere, eski silahlara, savaş kıyafetlerine, padişahların süslü hançerlerine ve kılıçlarına bakıp hayran kaldığını belirtir:

"Burada muharabe-i talabiye zamanından günümüze kadar hüküm süren ne kadar devlet varsa her birinin kendi zamanlarında kullanılan silahları, üstlerine giydikleri kıyafetleri, bayrakları, hepsi var. Bir tane de evvelki zaman bahadırlarının kullandığı, bizim gürz dediğimiz bir çokmar vardır ki hiç şüphesiz bir buçuk pot ağırlığındadır (1pot = $16.3 \mathrm{~kg}$.). Gürzü tek elle değil iki elle zar zor kaldırdım. Bu gürz ile birinin savaşa gitmesi için muhakkak Seyit Battal olması lazımdır” (Kamal, 2020:133).

Yazarın ilgisini yeniçeri dönemlerinden kalmış askeri davullar çeker: "Davul deyince bunlar sıradan davul diye farz edilmesin. Bunlar akıl ermez derecede büyük şeylerdir. Bu davulların içine otuz kova su koysan da dolmaz" (Kamal, 2020: 133).

Kamal, Türklerin, Askeri Müze'yi Avrupa'da bile eşi benzeri olmayan, çok zengin ve nadir müzelerden biri olduğunu iddia ettiklerini yazar. Bilindiği üzere XX. yüzyılın sonunda İstanbul'a gelen çoğu Rus gezgin de bu müzeyi ziyaret eder. Rus gezginler Askeri Müze’yi eskicilik ve vahşilik simgesi olarak kabul ederler. Oysa Kamal, burayı Türk tarihinin şanlı geçmişi, Osmanlı Devleti’nin askeri gücünün yansıması olarak değerlendirir.

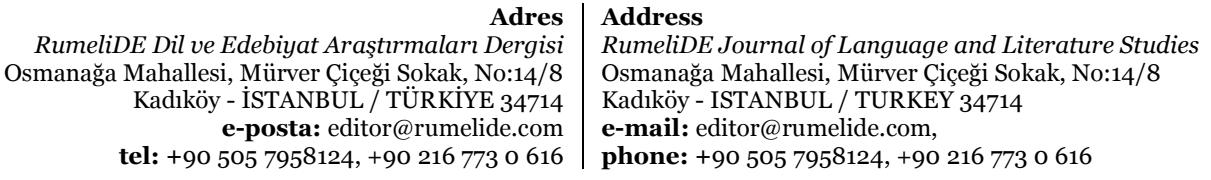


Kamal, Türk ordusunun sadece geçmişteki şanlı tarihinden bahsetmekle kalmayıp o günkü durumunu da anlatmaya önem verir. Bu bağlamda yazar eğitim ve sağlı sistemlerinde yapılan yeniliklerin yanı sıra ülkede yürütülen askeri reformlardan da söz eder. Bilindiği üzere o dönemde donanmayı kuvvetlendirmek için yeni savaş gemilerinin temini ve Türk filosunu güçlendirmeye yönelik faaliyetler öncelik kazanmıştır. Bu amaçla Türkiye'nin İngiliz ve İtalyan hükümetleriyle işbirliği yaptığı ve onlardan destek aldığı da belirtilir. Genel olarak Kamal, Türkiye'nin ilerleme arzusunun güçlü olduğunu, yeni ve modern bir devlet olarak öne çıkma isteğinin büyük olduğunun altını çizmektedir. Yazarın düşüncelerine göre; hedeflere ulaşmak için çok sayıda değişik plan ve projeler mevcuttur ancak bunları hayata geçirmek için zamana ihtiyaç duyulmaktadır.

\section{Savaşı anlatmak}

İstanbul Mektupları'nda, Balkan Savaşı esnasında, Türkiye'de özellikle İstanbul'da cereyan eden olaylarla ilgili yapılan değerlendirmeler sıkça karşımıza çıkar. "Eserin başından sonuna kadar bu konu çeşitli biçimlerde ele alınır: devamlı savaşa hazırlı faaliyetleri yürütme (asker uğurlama, her gün vagonlar dolusu erzak gönderme); savaşın sonuçları (yaralılar, hastaneler); savaşın ülke ekonomisine, toplumun yaşantısına olumsuz etkileri (gıda fiyatlarının artması vs.)" (Aleeva, t.y.). Eserin üçüncü bölümünde Türk savaş gemilerinin Akdeniz'de Yunanistan'ın en büyük gemilerinden olan "Avarov" adlı dretnot gemisini devre dışı bırakmaları; diğer bir Yunan gemisinin de esir alınması ile ilgili haberlere yer verilmiştir. Sevinç ve gurur kaynağı olan bu haberler Türk askeri ve halkını çok etkiler ve zafere olan inancını arttırır. Yazar, Kırk Kilise Muharebesi'ne katılan bir Türk askerinin söylediklerinden yola çıkarak cephedeki olayları da anlatır. Asker, orduya erzak temin etmede ortaya çıkan sıkıntıları, var olan gıdanın da düşmanın eline geçmesini, kurşunların tükenmesini, yenilgilerinin nedenlerini açıklamaktadır.

Mektuplarda dünyanın dört bir yanından gelen ve savaşa gönüllü katılan Müslümanlardan da bahsedilmektedir. Yazarın verdiği bilgilere göre dışarıdan gelen askerlerin arasında "Rusya'dan (Kırım'dan ve gayrı yerlerden) gelen kişiler de üç yüz kadar vardır. Moskova'da Yüksek Ticaret Mektebi'nde okuyan Arif Efendi Kerimev birkaç kere savaşa katılıp sonunda sol kolundan yaralanmış, hâlen tedavi görüyor" (Kamal, 2020:128). Aynı şekilde cephede yaralanıp hiç Türkçe bilmediğinden Türk devriyesine kim olduğunu anlatmak için şehadet kelimesi söyleyerek avaz avaz bağırmak zorunda kalan Arap askerinin hikâyesi de yer alır.

Kamal, İstanbul'a geldiği günlerde geçici bir sulh ilan edilmiş olmasına rağmen halkın bu habere pek inanmadığını ve o zamanki iktidarı hiç desteklemediklerini belirtir. Yazarın fikrine göre iktidar her ne kadar barış taraftarı olsa da halk "yeniden Bulgarlarla savaşıp kendi yüzlerine sürülen pisliği yıkamak istiyor”. Kamal, savaşın getirdiği zorlukların Türk milletinin moralini hiç bozmadığını, tam tersine halkın vatanseverlik duygularının artmasına sebep olduğunu vurgular; halkın düşmanı yenmek ve vatanını korumak için tüm gücüyle savaşa hazır olduğunu belirtir.

Elbette böyle bir dönemde aziz vatana sahip çlkmak ve hürriyeti korumak Türkler için ne kadar önemliyse bir an önce barışın sağlanması da mühim bir mesele olmuştur. Barışın imzalanması Türkler kadar başka milletler için de arzulanan bir konu olmuştur. Yazar hem Türklerin hem de başka halkların hayatlarının ticarete dayalı olması ve ticaretin yürütülebilmesi için de ülkede barışın sağlanmış olmasını bunun nedeni olarak görmektedir: "Türklerden başka kavimlerin derhâl sulhu istemelerinin de sebebi malum çünkü onların ekserisi ticaret erbabıdır, savaş dolayısıyla ticaret de

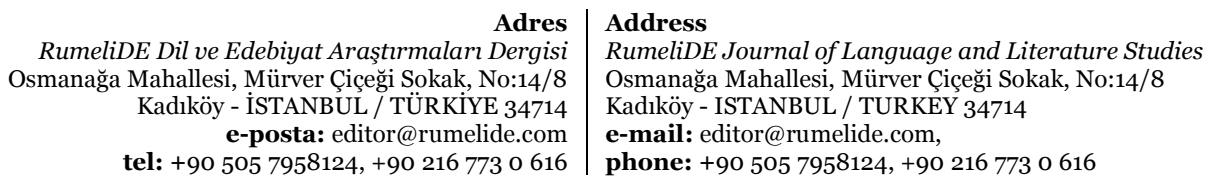


durgun. Alışveriş kötü, harici ticaret pek az. Pek çok ticaret firmasının çatlayıp gitmesi bundandır" (Kamal, 2020:150).

\section{İklim ve insan}

Kamal, Türkler ve ülkede yaşanan olaylardan bahsederken doğa, iklim koşullarının insanın düşünce ve davranış biçimlerini etkilediğini öne sürmüş, insanların savaşa ve hayata olan yaklaşımlarını İstanbul'un hava durumuna bağlı olarak anlatmaya çalışmıştır. Yazar, iklim değişikliğinin insanların sağllğı ve psikolojisi üzerindeki etkisini vurgulayarak bu konuya dair bazı örnekler vermiştir:

"Son günlerde asker içi bir sıkıntı baş gösterdi. Bugüne kadar İstanbul'da havalar sıcak ve güneşli idi. 20 Aralık'a doğru geceleyin hava birden değişip soğudu. O gece 4 dereceye kadar soğuyup sular dondu. O günden beri az da olsa soğuk devam ediyor ve hemen her gün yağmur yağıyor. Havanın kötüleşmesi askere çok tesir etti. Asker arasında hastalıkların artmasına sebep oldu. Bu günlerde Çatalca'dan binlerce hasta asker İstanbul'a gelmeye başladı. Son günlerde boşalmakta olan hastaneler tekrar askerle dolmaya başladı" (Kamal, 2020:141).

Havalar güzelken savaş taraftarı olan Türkler, hava durumunun kötüleşmeye başlamasıyla sulh hakkında konuşmaya başlar:

“İstanbul'da havalar tamamen bozuldu. Geceleri kar yağıyor, gündüzleri yağmur yağıp bütün sokakları çamura batırıyor. Her yerde rutubet ve soğuk hüküm sürüyor. Havanın kötülüğü ahaliye pek kötü tesir ediyor. Bundan birkaç gün evvel kendilerini pek sağlam ve kuvvetli farz eden ve savaş taraftarı olan Türkler bugün sulh taraftarı olmaya başladılar” (Kamal, 2020:142).

Kamal, İstanbul'daki evlerin Rusya'daki gibi soğuk kış şartlarına uygun ve sağlam yapılmadığını ve dolayısıyla insanların soğuktan çok etkilendiğini belirtir. Buna bağlı olarak yazar iltihaplanma, dizanteri ve romatizma hastalıklarının halk arasında çok yaygın olduğunu belirtir.

Kamal, Türkiye'deki siyasi hayatın çok karışık ve değiş̧en olduğunu belirterek iklim şartları ile ilişkilendirir: "Sonbahar ve kış günlerinde İstanbul'un havası ne kadar çabuk değişiyorsa Türkiye'nin siyaset âlemi de o kadar çabuk değişiyor. Bugün sabahki mevcut durum akşamkine benzemiyor" (Kamal, 2020:139).

\section{Yabancilar}

Kamal mektuplarında Osmanlı'da çok sayıda yaşayan yabancıların hayatını da dile getirmektedir. Osmanlı'yı ziyaret eden Rus gezginlerin ve yazarların eserlerinde daha çok Ermeni, Rum ve Yahudi asıllı vatandaşlardan bahsedilirken Kamal daha çok Osmanlı'nın Müslüman tebaasından söz eder. Özellikle de Osmanlı'da yaşamakta olan Tatarların hayatından bolca örnekler verir. Yazar, önceleri kendi milletinden olan Tatarları "geride kalmış, işe yaramayan kişiler" olarak düşünürken Osmanlı'ya gelip buradaki Tatarların durumunu gözlemleyince fikrinin olumlu yönde değiştiğini belirtir. Yazar, Türkiye'nin neredeyse her devlet kuruluşunda, her devlet dairesinde Tatarların çalıştıklarını, toplum hayatına katkıda bulunduklarını görüp kendi milleti ile gurur duymaya başlar:

“İstanbul'da en iyi hatip sayılan kişi Tatardır. Gazete idarelerinde en iyi yazarlardan sayllan muharrirler Tatarlardır. Türkiye'nin Erkân-ı Harb üyeleri arasında da bir Tatar var. Türkiye'nin idadi mekteplerinden birisinde de bir Tatar muallim vardır. Bundan başka diğer dairelerde de Tatarlardan

\footnotetext{
\begin{tabular}{r|l} 
Adres & Address \\
RumeliDE Dil ve Edebiyat Araşttrmaları Dergisi & RumeliDE Journal of Language and Literature Studies
\end{tabular} Osmanağa Mahallesi, Mürver Çiçeği Sokak, No:14/8 Osmanağa Mahallesi, Mürver Çiçeği Sokak, No:14/8 Kadıköy - İSTANBUL / TÜRKIYE 34714 Kadıköy - ISTANBUL / TURKEY 34714 e-posta: editor@rumelide.com e-mail: editor@rumelide.com, tel: +90 505 7958124, +90 2167730616 phone: +90 505 7958124, +90 2167730616
} 
işi başında olan kişileri görmek mümkündür. Bu işleri gördükten sonra eğer gayret etseler bizim Tatarların da ellerinden iş gelecekmiş diye fikirler aklıma geldi” (Kamal, 2020:130).

Genel olarak Tatarların, Osmanlı'da çalışkan ve becerikli olmalarıyla ün salmış olduklarını belirtir. Osmanlı'daki Tatarların yaşamları ve çalışmaları ile yakından tanışan Kamal, Tatarların da dereceli, seçkin yerlerde çalışabildiklerini yazar. Ayrıca Rusya'dan farklı olarak Osmanlı topraklarında Tatarların da yüksek makamlara ulaşma imkânına sahip olduğunu belirtir:

"Türkiye'de umumen, Tatarlar çalışkanlıkları ve iş görebildikleri ile meşhurdur. Hatta iyi çalıştıkları ile şöhret kazanan memurlar da Tatarlardandır. Mesela bugün Maliye Nazırı Abdurahman Bey Tatardır. Paşalardan, memurlardan, muallimlerden pek çok kişi Kırım'dan veya Kafkasya'dan gelen Tatardır. Türk diye farz edilen, görünen bir kişiyi biraz teftiş edip baksan aslı veya kendisi Tatar çıkar" (Kamal, 2020:137).

Yazar, bu konuyu Rusya'ya döndükten sonra da işlemeye devam eder. Basın müdürü olarak çalıştığı gazetede özgürlüklerinin kısıtlandığı ve hukuki eşitsizliğin hüküm sürdüğü koşullarda yaşamak zorunda kalan Tatarlarla ilgili makaleler yazar. Çarlık Hükümetine karşı yazdığı makalelerden dolayı suçlanır ve dava açılır. (Glyzzet, 2010:344).

Kamal'ın İstanbul'daki hayatı gayet hareketli geçer, yazar her şeyi görmeye ve öğrenmeye çalışır; Rusyal Talebe Cemiyeti meclislerine katılır, onların faaliyetleriyle yakından ilgilenir. Bu cemiyetin yüz elli kadar üyesi olduğunu, okuma salonlarında Rusya'da yayımlanan gazete ve dergilerin de yer aldığını belirtir.

Ayrıca Kamal, İstanbul'da yayımlanmakta olan Türk Yurdu Dergisi’nin idare binasını ziyaret eder; derginin genel yayın yönetmeni olan Tatar asıllı Yusuf Akçura ile görüşmek ister. Ancak Yusuf Akçura'nın yerinde olmaması sebebiyle bu görüşme gerçekleşemez ve yazar derginin başyazarlarından Kazım Nebi ile tanışır, onunla edebiyat ve dil üzerine uzun uzun sohbet eder.

İstanbul Mektupları'nda sadece Kazan Tatarlarından değil, savaş veya zor hayat koşullarından kaçıp Osmanlı'ya mülteci olarak yerleşen diğer Türk boylarından da bahsedilir. Aynı zamanda Kamal sadece İstanbul gibi merkezde değil, Anadolu'ya gidip yerleşen mültecilerden de söz eder; Anadolu köylerinde yaşayan çiftçilerin hayatından örnekler verir. Bu bağlamda Osmanlı hükümetinin ülkede gerçekleştirmeye çalıştığı tarım reformlarını ele alır; Müslüman olma şartıyla Anadolu'nun verimli topraklarına yerleşmek isteyen yabancılara ne tür imtiyaz ve yardımların yapıldığını anlatır. Kamal, Anadolu demiryolu boyunca dışarıdan gelip yerleşen iki yüz kadar muhacir köyünün ortaya çıtığını, çoğunun da Kırım Tatarlarından oluştuğunu belirtir: "Bugünkü günde Anadolu demiryolu üstüne dışarıdan gelip iki yüz kadar köye muhacirler yerleşmiş. Bunlar arasında toprağı iyi işleyen, Kırım'dan göç eden Tatarlardır. Bunlar diğerlerine nispeten pek güzel zenginleşmiş” (Kamal, 2020:137). Yazarın bu konuya dikkat çekmesinin asıl sebebi Kazan tatarlarının bu mesele ile yakından ilgilenmeleri ve önem vermeleridir. Bilindiği üzere XIX. yüzyılda ve sonrasında çok sayıda Tatar ailesi Rusya'dan Osmanlı topraklarına göç eder ve burada ikinci vatanını bulur. Dolayısıyla Osmanlı Devleti'nin bu konuda yürüttüğü politika ve izlediği yol hep merak konusu olmuştur.

Kamal, İstanbul'da çok sayıda muhacirin bulunduğunu belirterek hükümetin onlara yardım ve destek konusunda attığı adımları sıralar. Türk halkı da muhacirlere yardım eli uzatarak onlara her türlü yardımda bulunur: "Onlar camilere yerleştirilip, hazineden yiyecekleri karşılanıp Anadolu tarafına

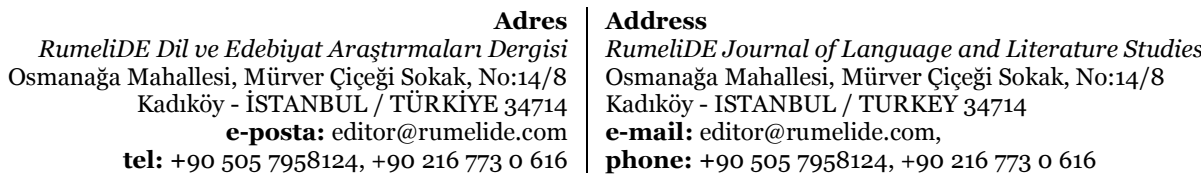


iskân edilmişler. Bugün de İstanbul'un birkaç yerinde böyle muhtaçlara bedava çay içirip karınlarını doyuruyorlar" (Kamal, 2020:130).

Kamal, sadece Müslümanları anlatmakla kalmaz, Osmanlı'nın gayrimüslim tebaasının da hayatını aydınlatmaya önem verir. Rus gazetelerinde yayımlanan İstanbul'daki hayat ve savaş ile ilgili bazı yalan yanlış haberlere açıklık getirir, yeni bilgilerle durumu anlatır. Örneğin "savaşın ilk dönemlerinde Hristiyanlar Bulgaristan'a karşı çıkmaktan imtina ederek Bulgaristan tarafına kaçmışlar” diye çıkan haberlerin gerçeği yansıtmadığını, hastanede yatan yaralılar arasında gayrimüslimlerin de olduğunu belirtir. Kamal, savaşın İstanbul'a yaklaşmış olmasının, kendi ifadesiyle "savaş olaylarının Çatalca gibi arka bahçede" devam etmesinin İstanbul'da yaşayan Hristiyanların da yaşam şartlarını etkilediğini ancak Hristiyanlara karşı saldırı gibi çirkin olaylara hiç rastlanmadığını bildirir.

\section{İç siyaset}

Kamal, İstanbul Mektupları'nın dördüncü bölümünde Türkiye'nin iç siyaseti, özellikle de çeşitli partiler arasındaki iktidar mücadelesinden bahsetmektedir. "Galiesgar Kamal bu noktada kendisini siyasi konular üzerine analitik fikir yürüten gazeteci olarak göstermektedir” (Aleeva, t.y.). Yazar oluşmakta olan yeni partinin lideri Lütfi Fikri'den bahseder; onu hürriyet ve özellikle de Türk kadınlarının toplum hayatına katılmaları ve hakları konularına önem veren bir siyasetçi olarak tanıtır. Genel olarak Kamal, savaş sona erse de partiler arasında iktidar mücadelesinin devam edeceğini ve ülkede büyük değişimlerin meydana geleceğini öngörür.

Mektuplarda Türkiye'nin iç siyaset konusu devam ettirilerek "Türkiye'de Büyük Değişiklikler" olarak adlandırılan on birinci bölümde Bab-ı Ali Baskını ile ilgili yazı yer almaktadır. Bu bölümde ülkenin iç siyasetinde büyük değişimlere sebep olan Hükümet darbesiyle ilgili olaylardan bahsedilmektedir. Bilindiği üzere "Enver Bey ile İttihat ve Terakki Cemiyeti’nin ileri gelenleri 23 Ocak 1913 tarihinde Bâbıâli Baskınını gerçekleştirdiler. Enver Bey öncü rol oynadığı bu hükümet darbesinde Kâmil Paşa'ya istifanamesini imzalattı. Ardından padişahı ziyaret ederek Mahmut Şevket Paşa'nın sadarete getirilmesini sağladı" (Hanioğlu, 1995:11:262). Kamal, İstanbul'da bulunduğu dönemde gerçekleşen ve Türkiye tarihinde büyük önem taşıyan bu olayların ayrıntılarını Tatar okurlarına aktarabilmek için Enver Paşa ile içeri giren (Bab-ı Ali'ye - İ.R.) tanıklarla görüşür: "Türk milleti Kırk Kilise mağlubiyetinden beri bu hükûmet erbabından memnun değildi. Ne yapıp edip bu kabineyi gözden düşürmeyi düşünüyorlardı. İttihat ve Terakki Fırkasının sahipleri de bu fikirle meşgul idi. İttihatçılar bir aydan beri bu kabinenin bir şekilde istifa etmesi için gayret ettiler” (Kamal, 2020:145). Kamal, halkın Enver Paşa'yı desteklediğini; askerlerle bir olup Edirne ve adaların düşman elinden geri alınması gerektiğini savunduğunu, gerekirse savaşmaya da hazır olduğunu beyan eder. Kamal'ın fikrine göre Hükümet bu savaşa hazırlıksız yakalanmış, trenler dolusu yaralılar gelmeye başlayınca da "bütün İstanbul halkı birden ayağa kalkıp yaralılara yardım etmeye" (Kamal, 2020:131) başlamış.

\section{Türk imgesi}

Yazar, Türk savaşçılarının kahramanlığına, onların fedailiklerine övgüler yağdırır: "Bugüne kadar Türkler savaşta yenilmeyi öğrenmemişler. Hemen hemen her zaman onlar savaşta galip gelmişler. Bu sebeple onlar hiç yenilmeyi düşünmemişler" (Kamal, 2020:131). Bu vesile ile yazar savaşa gitmeye hazırlanan bir Türk askerinin ruh halini yansıtan bir olayı da anlatır: "Zabitlerden biri bir dükkânda iki kuruşluk tütün istemiş. Dükkân sahibi: 'Siz muharebeye gidiyorsunuz, daha çok alın!' deyince 'Zarar yok, gerek olursa Sofya şehrinde yine alırım' demiş” (Kamal, 2020:131). Yazara göre bu satırlar Türk

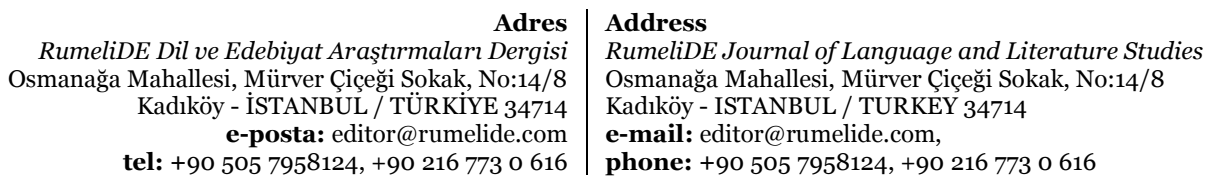


askerinin savaşta galip geleceğinden emin olduğunu; hiçbir engelin onu amacından alıkoyamayacağını gösteren bir olgudur.

Bilindiği üzere Avrupa veya Rusya'dan gelen gezginlerin çoğu, Osmanlı'daki kahve kültürü üzerinde durur. Bu konu Kamal'ın da ilgisini çeker ve kendi toplumunda benzeri bulunmayan bu tür kültürel ögelerin tasvirine eserinde yer verir. İnsanların birlikte toplanıp sohbet ettiği ve her türlü konunun konuşulduğu kahvehane kültürünü Kamal boş zaman geçirme olarak değerlendirir:

"Onlar ekseri kahvehanelerde sabahtan akşama kadar siyasetten, vakıalardan ve başka şeylerden bahsedip oturmayı, başka türlü iş, meşakkat veya hizmet ile meşgul olmaktan daha çok severler. İstanbul'un bitmez tükenmez sayısız kahvehaneleri gündüzleri de halkla dolu olur. Akşam olunca ise girip oturacak yer olmaz. Sobasız soğuk evlerde üşüyüp donarak oturmaktansa kahvehanelerde ısınıp oturmayı bunlar tabii ki daha çok severler” (Kamal, 2020:137-138).

Türkleri "rahatına düşkün halk" olarak nitelendiren yazar Türk erkeklerinin "evlerine sadece yatıp uyumaya" gittiklerini belirtir. Zamanını evlerinde değil de daha çok kahvehanelerde geçirmeyi seven Türk erkekleri ile ilgili şu satırlara yer verir: "Mübalağa olmasın, akşamları erkeklerin onda biri de evlerinde oturmazlarmış. Bunları gören bir adam bu çevrede epeydir savaş varmış, şehirden yirmi beş kilometre yerde düşman askeri vardır diye düşünemez" (Kamal, 2020:138).

\section{Sonuç}

Hastalanması nedeniyle Kamal, Kazan’a geri dönmek için yola çımak zorunda kalır. Yazar, Türkiye ile ilgili son fikirlerini "Son Gün Hatıraları” diye adlandırdığı on ikinci bölümde özetler. Savaş olayları ve toplum hayatını aydınlatmayı amaçlayan yazar, Türklerin zafere inançlarını, daima ülkelerinin hürriyeti için mücadele halinde olduklarını gayet açık bir şekilde aktarmıştır. Yazarın gözlemlerinden, son darbenin etkisiyle halkın milliyetçi duygularının daha da arttığı, vatanlarını korumak için tüm güçleri ve enerjileriyle sonuna kadar mücadele etmeye hazır oldukları anlaşılmaktadır.

İstanbul Mektupları, sürekli değişen günlük gelişmelerin sıralı anlatımı üzerine inşa edilen bir eserdir. Yazar, Balkan Savaşı’nın etkilerini anlatmayı amaçladığı bu eserinde, o dönem Türkiye'sindeki yaşamı, halkın savaşa karşı tutumunu, vatanseverlik duygularını, çatışmalı iç ve dış siyaseti çok güzel bir şekilde betimlemiştir. İstanbul Mektupları'nın, Tatar edebiyatındaki seyahatname türünü zenginleştiren bir eser olduğunu da belirtmek gerekir. Kamal, hastalığı nedeniyle Kazan'a döndükten sonra onun işini devam ettirmek için G. Ebüzerov adlı gazeteci İstanbul'a gelir ve Yoldız Gazetesine haberler yollamaya başlar. Yaklaşık 20 mektuptan oluşan ve daha çok Osmanlı'nın dış siyasetini ele alan G. Ebüzerov'un İstanbul Mektupları adlı eseri, henüz araştırılmamıştır.

Galiesgar Kamal'ın İstanbul Mektupları, Balkan Savaşı esnasında halkın toplumsal, siyasi ve gündelik hayatının ayrıntılarını, insanların psikolojik durumunu anlatan bir eserdir. Yazar, Türkleri "sakin", "rahatlarına düşkün" bir halk olarak tanımlamaktadır. Aynı zamanda siyasette aktif, ülke çapındaki gelişmelerin içinde yer alan, düşmanla mücadelede ön safta savaşan "korku bilmez" insanlar olarak betimlemektedir.

Yazar eserinde başka ülkeleri ve halkların hayatını tasvir etmiş olsa da asıl amacı Rusya'da yaşayan Müslümanların trajik durumuna dikkat çekmektir. Kamal, sıkı sansür nedeniyle fikirlerini açıkça ifade edememiş olsa da onun bu düşüncelerini satır aralarında okumak mümkündür. Yazar, siyasi özgürlükten yoksun Tatar halkının istikbali ile ilgili endişe ve üzüntü duymaktadır. Bağımsız Osmanlı

\begin{tabular}{r|l} 
Adres & Address \\
RumeliDE Dil ve Edebiyat Araşțrmaları Dergisi & RumeliDE Journal of Language and Literature Studies \\
Osmanağa Mahallesi, Mürver Çiçeği Sokak, No:14/8 & Osmanağa Mahallesi, Mürver Çiçeği Sokak, No:14/8 \\
Kadıöy - İSTANBUL / TÜRKIYYE 34714 & Kadıköy - ISTANBUL / TURKEY 34714 \\
e-posta: editor@rumelide.com & e-mail: editor@rumelide.com, \\
tel: +90 505 7958124, +90 216773 o 616 & phone: +90 505 7958124, +90 216773 o 616
\end{tabular}


Türklerinin ise geleceğinin güzel olacağına, vatanlarını koruma ve özgürlüklerini savunma yolunda birlik olabileceklerine ve cesurca son damla kanlarına kadar savaşacaklarına inanmaktadır.

\section{Kaynaklar}

Aleeva, E. (t.y). Galiesgar Kamalnın İstanbul Mektüplerende Janr Hasiyetlere. http://gabdullatukay.ru/tukay-environment/galiesgar-kamal/enise-aleeva-galiesgar-kamalnynlaquo-istanbul-mektublere-raquo-nde-zhanr-hasiyatlere/.

Giyzzet, B. (2010). Galiesgar Kamal'ın Revolyutsiyege Kaderge İjatı. Galiesgar Kamal. Eserler. Kazan: Tataristan Kitap Neşriyatı. 341-356.

Eydi, T. (2004). Hazineler Ortak: Türk-Tatar Münasebetleri. (Türkçeye aktaran Birsel Oruç Aslan). Türklük Araştırmaları Dergisi, 15 (Bahar), 303-344.

Hanioğlu, M. Ş. (1995). Enver Paşa. TDV İslâm Ansiklopedisi. TDV İslam Araştırmaları Merkezi. https://islamansiklopedisi.org.tr/enver-pasa

Kamal, G. (2020). İstanbul Mektupları (1912, İstanbul, Balkan Savaşı). (Akt. M.Öner). Türk Dünyası Dil ve Edebiyat Dergisi, 50, 117-152.

Kefeli, E. (2002). Anlatım Tekniği Olarak Mektup. İstanbul: Kitabevi.

Öner, M. (2012). Galiesgar Kamal ve İstanbul Mektupları. 7 Uluslararası Türk Kültürü Kongresi, Bildiriler III. Konya: Atatürk Kültür Merkezi Yayını, 515-524.

Zaripova Çetin, Ç. (2018). XX. Yüzyıl Kazan Tatar Edebiyatı. Türk Dünyası Çağdaş Edebiyatları El Kitabl. İstanbul: Kesit, 569-824.

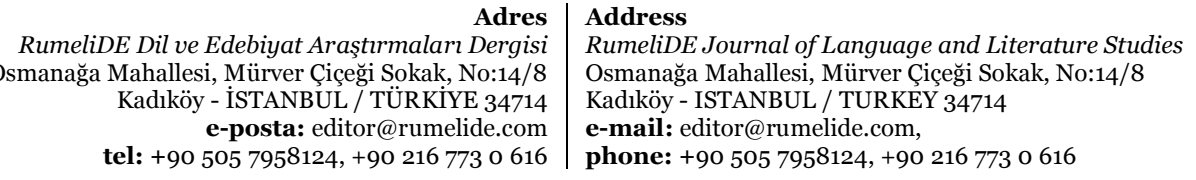

